\title{
QUALITY MODEL BASED ON PLAYABILITY FOR THE UNDERSTANDABILITY AND USABILITY COMPONENTS IN SERIOUS VIDEO GAMES
}

\author{
Iván Humberto Fuentes Chab, Damián Uriel Rosado Castellanos, Olivia \\ Graciela Fragoso Diaz and Ivette Stephany Pacheco Farfán \\ Department of Computer Systems Engineering, Instituto Tecnológico Superior \\ de Escárcega (ITSE), Escárcega, México
}

\begin{abstract}
A serious video game is an easy and practical way to get the player to learn about a complex subject, such as performing integrals, applying first aid, or even getting children to learn to read and write in their native language or another language. Therefore, to develop a serious video game, you must have a guide containing the basic or necessary elements of its software components to be considered. This research presents a quality model to evaluate the playability, taking the attributes of usability and understandability at the level of software components. This model can serve as parameters to measure the quality of the software product of the serious video games before and during its development, providing a margin with the primordial elements that a serious video game must have so that the players reach the desired objective of learning while playing. The experimental results show that $88.045 \%$ is obtained concerning for to the quality model proposed for the serious video game used in the test case, margin that can vary according to the needs of the implemented video game.
\end{abstract}

\section{KEYWORDS}

Quality Model, Serious Video Games, Playability Metrics.

\section{INTRODUCTION}

Each day increases the amount of information and educational content on the Internet; however, it is difficult for a person to concentrate and motivate to devote time and effort to a specific topic. It's for this reason that educational video games are developed with the objective that the player manages to learn while having fun. These are known as Serious Video Games [1].

A serious video game is an easy and practical way to make a player learn about a complex topic such as integrals, can help people without medical knowledge to learn about first aid or simple topics for children to learn to read, write, or even another language.

That is why to develop a serious video game you must have a guide on the basic or necessary elements of its components to consider [2]. This document presents a quality model for playability, taking the measurement attributes of usability and understandability.

It is important to note that a quality model can be extensive and sometimes contains certain criteria, in this case, they are metrics that may not be applicable to the project. In section 5, the experimental results obtained during the analysis phase up to the development of a serious video game are presented. Which can serve as measurement parameters of the quality of the serious

David C. Wyld et al. (Eds): SPPR, NECO, GridCom, ICCSEA, SCAI, UBIC, SEMIT, MLDS - 2020 
video game software product before and during its development, to provide a margin that offers the best elements that a serious video game should bring to the players.

This paper is organized as: in section 2, related works have been discussed. We focus on the context of playability measurement as a quality attribute of understandability and usability software components for serious video games, in section 3 whereas section 4 the proposed quality model is presented along with its metrics. In section 5, we explain our findings i.e. results and discussions. At final section 6 concludes this research work.

\section{RELATED WORKS}

González-Sánchez et al., follow IEEE [3] expands the context of usability because it is not considered sufficient to measure the satisfaction of players, so it extends to attributes and properties that describe the player's experience within an environment, which is called as playability. A player-centered design is introduced to consider your gaming experience during the usability process in the software. The model proposed in this paper divides the playability into 6 facets having a total of 42 quality attributes, to measure from usability to playability [2].

There is a proposal of a quality model for serious games focused on functional suitability and 3 sub-characteristics and 12 attributes that entail [4]. The correctness, completeness and appropriateness are the attributes measured in this model where they are evaluated at the level of specifications and functionalities that allow to indicate suitable values for learning in serious games.

In [5], a heuristic evaluation is made to measure and test the usability of the games from a conceptual and design level that allows to increase and take advantage of the player's learning from inexperience to experience. A heuristic evaluation is made to the playability and usability where 10 attributes to be measured are listed in the use of the main elements of the game. To subsequently perform 11 measurement tests on these software components to heuristically identify a measured accessibility value in the usability and heuristic evaluation tests.

Chittaro [6] proposed a study on traditional learning by an instructor and through a serious video game that allows the passenger of an airplane to learn about the measures of help and safety to follow before, during and after take-off. This analysis consists of the comprehensibility that players have in their perception of vulnerability and severity, as well as recommendations and security control measures to provide a safe attitude and behaviour during the flight. This work makes a psychological study to measure the knowledge of risk control and perception in the recommendations and procedures to be followed in certain cases that may occur, incorporating 7 metrics to measure the knowledge of the players.

This research work proposes a quality framework to measure the playability with the attributes of usability and understand ability.

\section{MEASUREMENT APPROACH}

Serious Video Games are games whose main objective is not fun or entertainment, but learning or practicing a skill. They are used mainly in areas such as education, survival, self defense, science or health. They can have many purposes such as learning math, practicing a language, knowing our anatomy, training firefighting teams, or even first aid in cases of emergency. 
A game is defined as a playful exercise delimited by rules exercised voluntarily, while a video game is a playful exercise delimited by rules exercised voluntarily through specific hardware. A serious video game is a video game, since it shares the characteristics related to the technological support on which they are based, the circumstances in which they are derived must be considered [1].

The method that uses video games for learning purposes is known as game-based learning. The key lies in the fact that the content and the skills that you want to teach are not put across in a face-to-face class or in a book but rather through video games. Advocates of this method of teaching think that video games can be a fun and effective tool at one and the same time, reducing the costs of training programs, increasing student motivation and facilitating direct practice. The star products of game-based learning are precisely, serious games.

A Video Game is, at its most basic level, the implementation of a game in a computer-based console that uses some type of video output [7].

The model proposed in this paper is designed for any type of game, in such a way that its metrics can be adapted to the evaluation of the quality of its software components. For terms in the development of a Serious Video Game, we have the main processes and stages [8] in figure 1. It is worth mentioning that for the purposes of this work, the software components contained in a Serious Video Game will be considered, and not the stages of its development.

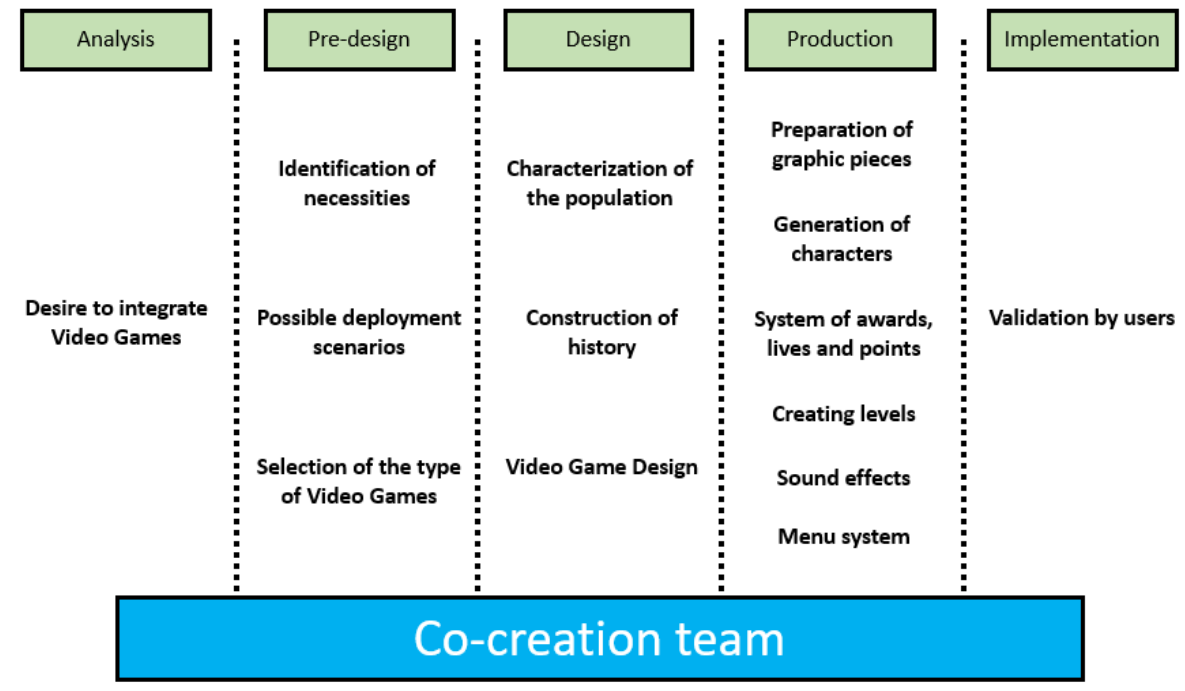

Figure 1. Model for the design and production of Serious Games

In figure 1 we have some key elements such as the possible deployment scenarios, preparation of graphic pieces, generation of characters and the creating levels. Which are elements of rendering and graphic design of all video games, these are:

- Packaging: packaging with promotional and popular graphic code, very attractive, that can be sold by themselves.

- User interface: it must be attractive, efficient, adaptable and meet the specific requirements of game mechanics and gender. It must be constantly tested and verified. 
- Promotional images, posters, web, stands, sprites: promotional pieces, similar to the material used in the film industry and in supermarkets. They must encourage the purchase of the product and inform where to buy it or how to consume it.

- Brand of product: in general, a powerful and popular graphic brand design is needed, since this type of products usually compete in the gondolas and in the virtual stores.

- Manuals: pieces of informative nature, with editorial typology.

Having in mind the stages and processes for the development of a video game, now we need to know the elements and software components that make up a serious video game.

Based on the attributes that allow us to evaluate through software quality metrics. For general terms of classifying the quality attributes of a video game these are divided into a two-layer architecture [9], as seen in figure 2.

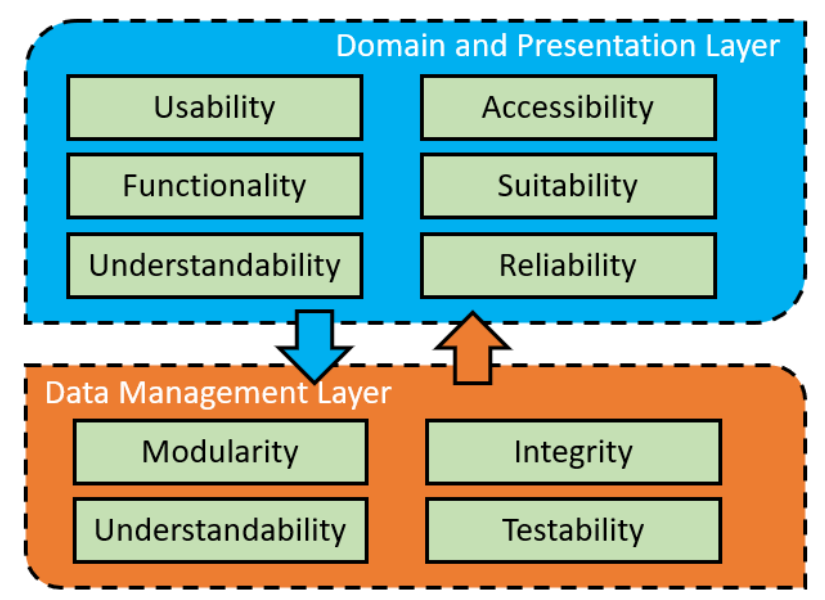

Figure 2. Quality Architecture by Two-Layers of a Video Game

From the point of view of software elements and components, there is a classic architecture in the development of video games divided into three layers [2] which can be seen in figure 3 .

- Game Mechanics: is the most important part of a video game, since it is formed by the set of elements that characterize and differentiate one game from another.

- Game Engine: refers to a series of routines that allow the execution of all elements of the game. It is where we must control how each element of the game is represented and how it interacts with them.

- Game Interface: is the part in charge of interacting directly with the player, and maintaining the dialogue between the player and the game. It is responsible for presenting all the contents, options, scenes of the virtual world, and also the necessary controls to interact within the video game, as well as show us the final look and feel of it. 


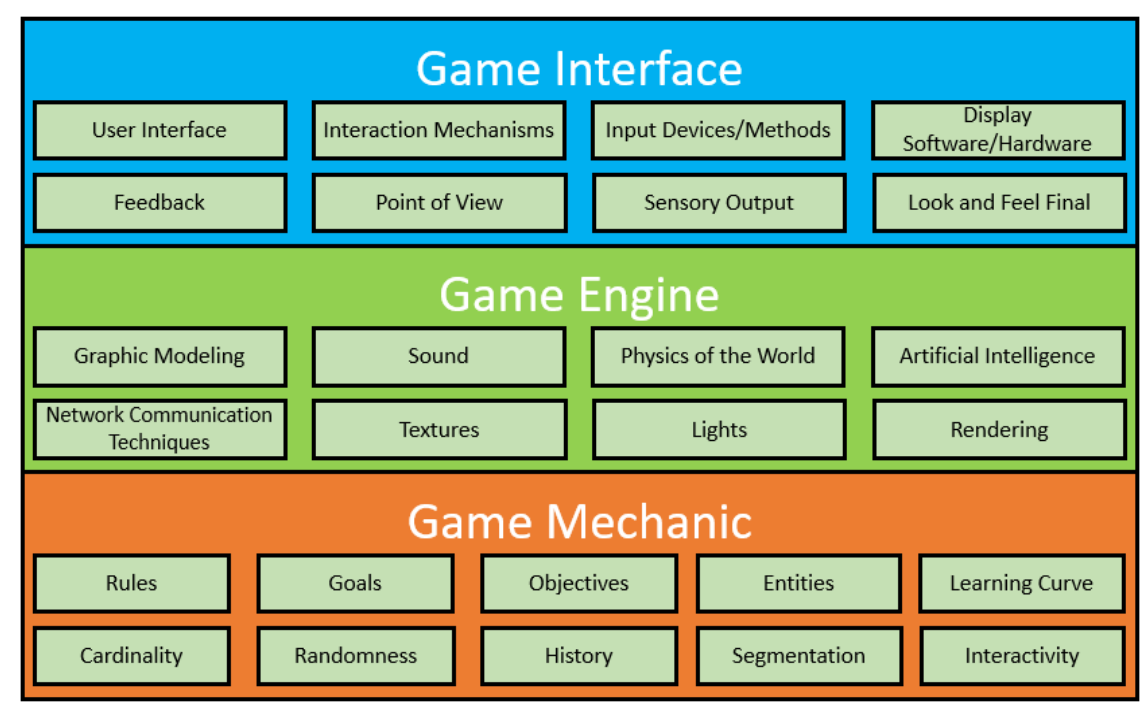

Figure 3. Classical Architecture by Layers of a Video Game

Playing is when the user interacts with a game. Within this interaction evolve the characteristics of the user experience (UX). In addition to the game system, the UX is strongly affected by the basic psychology always present and the user's background. The way in which psychology is represented in the UX depends on the content, that is, on the game [10].

We can appreciate this relationship between the video game system, the game and the psychology in a more concrete way in figure 4 , where the attributes of each of these elements are included.

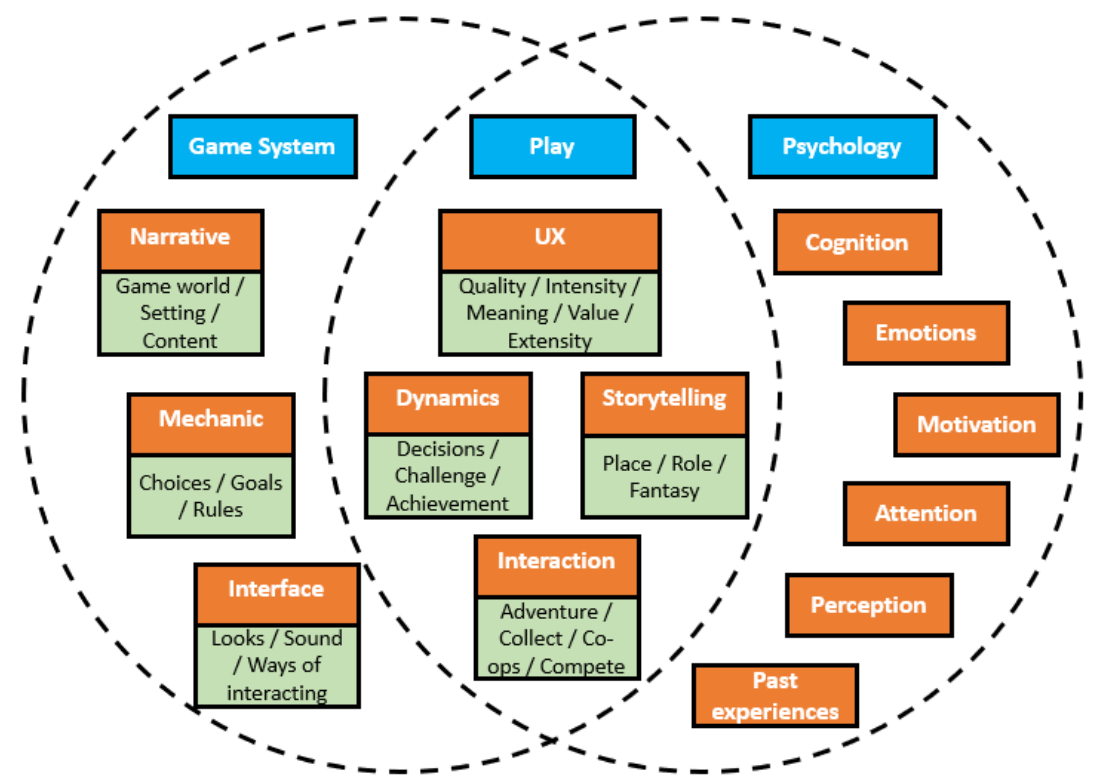

Figure 4. Psychology of user experience (UX) in Video Game Systems

\subsection{Quality Attributes to Measure}

In this model, the Domain and Presentation Layer of figure 2 will be measured, where only the attributes of Usability and Understandability will be considered. These quality attributes to be measured will be based on the elements of figure 3 and other elements of figure 4 that are 
considered important for the proposed model. Obtaining as a proposed result the hierarchy shown in figure 5 .

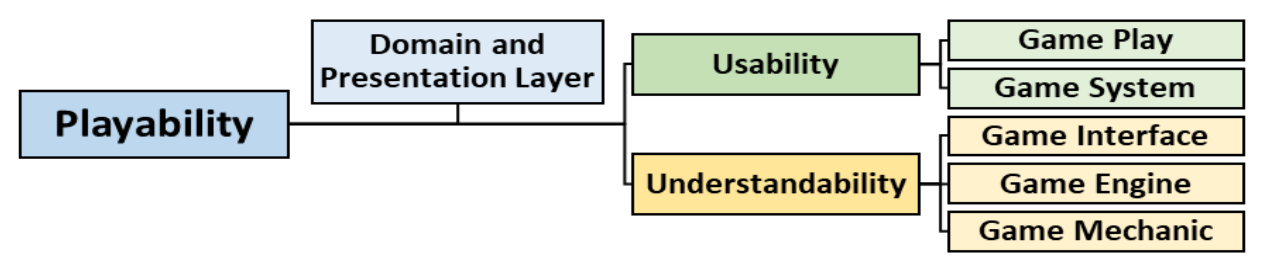

Figure 5. Playability as an attribute of quality to be measured for Serious Video Games

\section{Playability}

A set of properties that describe the Player Experience using a specific game system whose main objective is to provide enjoyment and entertainment, by being credible and satisfying, when the player plays alone or in company [2].

\section{Usability}

A set of attributes that relate to the effort needed for use, and on the individual assessment of such use, by a stated or implied set of users [3].

Considering the usability in the design of this model, the attributes of figure 3 will be taken as sub-characteristics adapting to the context of playability in serious video games:

- Game Play: the playability requires the intervention of the player with the game, where it will take an effort and time invested to play and master the mechanics of the game.

- Game System: the playability requires the intervention of the player with the game system, where it will require a decision making and interactions to master the dynamics of the game and can exploit the use of the game.

\section{Understandability}

A set of attributes of software that relate to the users' effort for recognizing the logical concept and its applicability [3].

Considering the understandability in the design of this model, the attributes of figure 2 will be taken as sub-characteristics adapting to the context of playability in serious video games:

- Game Interface: the playability requires the player to understand the game interface, in order to interact directly with the game.

- Game Engine: the playability requires the player to understand the game engine, to understand their environment and game environment.

- Game Mechanic: the playability requires the player to understand the game mechanic, to understand the rules and objectives to be achieved in the game. 


\section{QUALITY MODEL}

The software quality model for the attribute of playability in serious video games was as shown in figure 6.

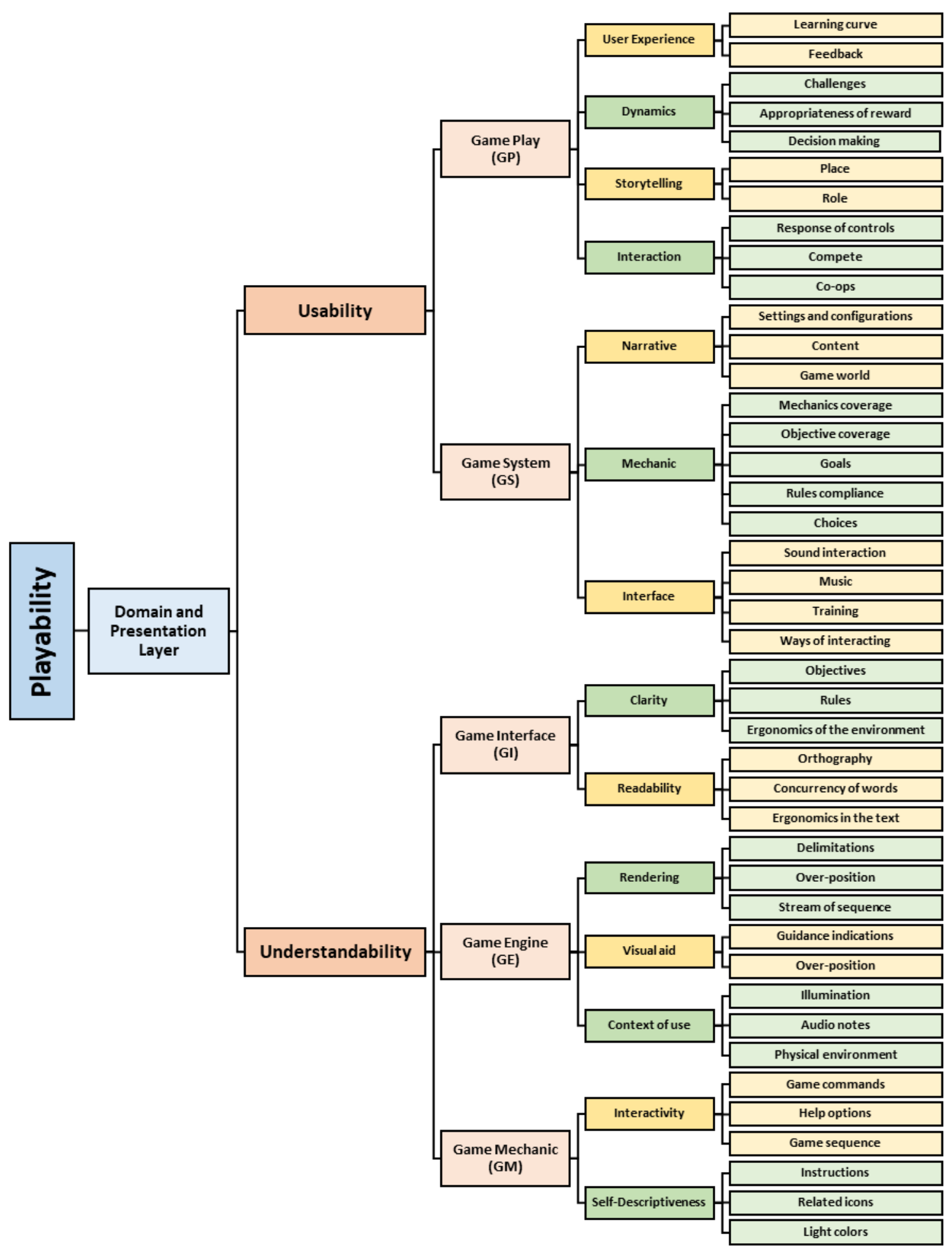

Figure 6. Quality Model for the Playability in Serious Video Games 


\subsection{Metrics Definition}

In this model, the quality model proposed in figure 6 will be taken to evaluate the playability attribute. Considering the sum obtained in the measurements of its usability and understandability sub-attributes, will be used Playability $=($ Usability + Understandability $)$.

The proposed model generalizes the types and roles of video games with the aim of focusing on the common software components among them. In such a way that the metrics defined have thresholds for any type or role of serious video games.

The result for the playability attribute is the sum between its usability and understandability, in order to reach a range between 0 and 100 . Where 0 indicates the lowest value and 100 indicates the highest value for the quality measurement of the software components in a Serious Video Game evaluated.

To measure the usability attribute, the results obtained in the Game Play (GP) and the Game System (GS) will be considered. The desired result for the usability attribute is 46, obtained from the sum between the GP and GS layer elements. To obtain the value of the usability attribute is used Usability $=(\mathrm{GP}+\mathrm{GS})$.

To get the GP value is necessary sum of its individual attributes, this is possible with the equation in equation 1.

$$
\begin{gathered}
G P=\sum_{i+1}^{n}\left[\left(\sum_{i+1}^{m} G P_{1}\right)+\left(\sum_{i+1}^{m} G P_{2}\right)+\left(\sum_{i+1}^{m} G P_{3}\right)+\left(\sum_{i+1}^{m} G P_{4}\right)+\left(\sum_{i+1}^{m} G P_{5}\right)+\left(\sum_{i+1}^{m} G P_{6}\right)\right. \\
\left.+\left(\sum_{i+1}^{m} G P_{7}\right)+\left(\sum_{i+1}^{m} G P_{8}\right)+\left(\sum_{i+1}^{m} G P_{9}\right)+\left(\sum_{i+1}^{m} G P_{10}\right)\right]
\end{gathered}
$$

Equation 1. Equation of the Game Play (GP) layer element

The desired result for the GP layer element is 22 , obtained from the sum of its 10 sub-attributes where each one has a maximum value of 2.2 , using the metrics to evaluate in table 1 .

\begin{tabular}{|c|c|c|c|c|}
\hline Attribute & Sub-Attribute & Metric & Weighting & Thresholds \\
\hline \multirow[t]{2}{*}{$\begin{array}{l}\text { User } \\
\text { Experience }\end{array}$} & $\begin{array}{l}\text { Learning curve = } \\
\mathrm{GP}_{1} \\
\text { Note: the learning curve } \\
\text { is considered when the } \\
\text { player repeats the same } \\
\text { level on at least two } \\
\text { occasions }\end{array}$ & $\begin{array}{l}\mathrm{GP}_{1}=(s t+t c+s h+ \\
h c+m c) \\
\text { - } \\
\text { - } \quad \text { Ttandard time }=s t \\
\quad t c \\
\text { - } \quad \text { Standard hits } \\
\text { reference }=\text { sh } \\
\text { - } \text { Hit counter }=h c \\
\text { - Mistakes counter } \\
=m c\end{array}$ & 2.2 & $\begin{array}{l}s t \text { exists }=0.44 \\
s t \text { doesn't exist }=0.0 \\
t c \text { exists }=0.44 \\
t c \text { doesn't exist }=0.0 \\
s h \text { exists }=0.44 \\
s h \text { doesn't exist }=0.0 \\
h c \text { exists }=0.44 \\
h c \text { doesn't exist }=0.0 \\
m c \text { exists }=0.44 \\
m c \text { doesn't exist }=0.0\end{array}$ \\
\hline & Feedback $=\mathrm{GP}_{2}$ & $\begin{array}{l}\mathrm{GP}_{2}=(a l+a n+h n+ \\
g n)\end{array}$ & 2.2 & $\begin{array}{l}a l \leq 2=0.55 \\
2<a l \leq 5=0.44 \\
5<a l \leq 8=0.33\end{array}$ \\
\hline
\end{tabular}

Table 1. Metrics of the Game Play (GP) layer element of the Usability attribute 


\begin{tabular}{|c|c|c|c|c|}
\hline & & $\begin{array}{ll}\text { - } & \text { Activities by level } \\
= & a l \\
\text { - } & \text { Activity notes }= \\
& \text { an } \\
\text { - } & \text { Hit notes }=h n \\
\text { - } & \text { Greeting notes = } \\
\text { gn }\end{array}$ & & $\begin{array}{l}8<a l \leq 10=0.22 \\
10<a l \leq 12=0.11 \\
a l>12=0.0 \\
\text { an equal to } a l=0.55 \\
a n \text { different to } a l=0.0 \\
h n \text { equal to } a n=0.55 \\
h n \text { different to } a n=0.0 \\
\text { gn equal to } a l=0.55 \\
g n \text { different to } a l=0.0 \\
\text { Note: the desired value } \\
\text { would be that there is no } \\
\text { more than } 1 \text { note per } \\
\text { activity; metric based on } \\
\text { [4] }\end{array}$ \\
\hline \multirow[t]{2}{*}{ Dynamics } & Challenges $=\mathrm{GP}_{3}$ & $\begin{array}{l}\mathrm{GP}_{3}=(c l+c m+d t+ \\
t m) \\
\text { - } \quad \begin{array}{l}\text { Challenges } \\
\text { level }=c l\end{array} \\
\text { - } \quad \text { byallenges met }= \\
\mathrm{cm} \\
\text { - } \quad \text { Desired time }=d t \\
\text { - } \quad \text { Time made }=t m\end{array}$ & 2.2 & $\begin{array}{l}c l \leq 3=0.55 \\
3<c l \leq 5=0.44 \\
5<c l \leq 7=0.33 \\
7<c l \leq 9=0.22 \\
9<c l \leq 11=0.11 \\
c l>11=0.0 \\
c m \leq 2=0.55 \\
2<c m \leq 5=0.44 \\
5<c m \leq 8=0.33 \\
8<c m \leq 10=0.22 \\
10<c m \leq 12=0.11 \\
c m>12=0.0 \\
d t \text { exists =0.55 } \\
d t \text { doesn't exist }=0.0 \\
t m \text { exists }=0.55 \\
t m \text { doesn't exist }=0.0 \\
\text { Note: the challenges are } \\
\text { the activities to be } \\
\text { fulfilled during each level } \\
\text { throughout the game in } \\
\text { order to meet the } \\
\text { objectives }\end{array}$ \\
\hline & $\begin{array}{l}\text { Appropriateness of } \\
\text { reward }=\mathrm{GP}_{4}\end{array}$ & $\begin{array}{l}\mathrm{GP}_{4}=(r a c+r l c) \\
\text { - } \quad \begin{array}{l}\text { Reward for } \\
\text { activity } \\
\text { completed }=r a c\end{array} \\
\text { Reward by level } \\
\text { completed = rlc }\end{array}$ & 2.2 & $\begin{array}{l}\text { rac exists }=1.1 \\
\text { rac doesn't exist }=0.0 \\
r l c \text { exists }=1.1 \\
r l c \text { doesn't exist }=0.0 \\
\text { Note: the desired value } \\
\text { should be considered } \\
\text { between percentage } \\
\text { ranks \% that take the } \\
\text { total of rewards among } \\
\text { the total of activities, but } \\
\text { not to generalize in a } \\
\text { type of video game is } \\
\text { assigned a unique binary } \\
\text { value; metric based on } \\
\text { [4] }\end{array}$ \\
\hline
\end{tabular}




\begin{tabular}{|c|c|c|c|c|}
\hline & $\begin{array}{l}\text { Decision making = } \\
\mathrm{GP}_{5}\end{array}$ & $\begin{array}{l}\mathrm{GP}_{5}=(t c+r a+m c) \\
\text { - } \quad \text { Timer counter }= \\
t c \\
\text { - } \quad \text { Response } \\
\text { alternative }=r a \\
\text { - Mistakes counter } \\
=m c\end{array}$ & 2.2 & $\begin{array}{l}t c \text { exists }=0.73 \\
t c \text { doesn't exist }=0.0 \\
r a \text { exists }=0.74 \\
r a \text { doesn't exist }=0.0 \\
m c \text { exists }=0.73 \\
m c \text { doesn't exist }=0.0 \\
\text { Note: decision making is } \\
\text { considered as a modality } \\
\text { of multiple options } \\
\text { during the video game }\end{array}$ \\
\hline \multirow[t]{2}{*}{ Storytelling } & $\begin{array}{l}\text { Place }=\mathrm{GP}_{6} \\
\text { Note: they are pieces that } \\
\text { must be delimited to } \\
\text { allow or restrict } \\
\text { movement }\end{array}$ & $\begin{array}{l}\mathrm{GP}_{6}=(\text { liex }) \\
\text { - Limit of } \\
\text { exploration of the } \\
\text { environment = } \\
\text { liex }\end{array}$ & 2.2 & $\begin{array}{l}m c \text { evaluate or consider } \\
\text { at least one action }=2.2 \\
m c \text { doesn't evaluate or } \\
\text { consider at least one } \\
\text { action }=0.0 \\
\text { Note: software } \\
\text { component based on the } \\
\text { graphic design pieces of } \\
\text { a video game; metric } \\
\text { based on [4] }\end{array}$ \\
\hline & Role $=\mathrm{GP}_{7}$ & $\begin{array}{l}\mathrm{GP}_{7}=(\text { awe }) \\
\text { - Actions with } \\
\text { other profiles or } \\
\text { objects in the } \\
\text { environment = } \\
\text { awe }\end{array}$ & 2.2 & $\begin{array}{l}\text { awe exists }=2.2 \\
\text { awe doesn't exist }=0.0 \\
\text { Note: software } \\
\text { component based on the } \\
\text { graphic design pieces of } \\
\text { a video game; metric } \\
\text { based on [4] }\end{array}$ \\
\hline \multirow{3}{*}{ Interaction } & $\begin{array}{l}\text { Response of } \\
\text { controls }=\mathrm{GP}_{8} \\
\text { Note: to expand this } \\
\text { work, other components } \\
\text { related to accessibility } \\
\text { can be considered }\end{array}$ & $\begin{array}{l}\mathrm{GP}_{8}=(a p c+n a p+ \\
\text { tpa }) \\
\text { - } \begin{array}{l}\text { Amount } \\
\text { pressured } \\
\text { commands }=a p c\end{array} \\
\text { Number of } \\
\text { actions performed } \\
=n a p \\
\text { Time to perform } \\
\text { the actions = tpa }\end{array}$ & 2.2 & $\begin{array}{l}\text { apc }<1=0.72 \\
1<a p c \leq 2=0.48 \\
2<a p c \leq 4=0.24 \\
\text { apc }>4=0.0 \\
\text { nap equal to } a p c=0.74 \\
\text { nap different to apc }= \\
0.0 \\
\text { tpa exists }=0.74 \\
\text { tpa doesn't exist }=0.0\end{array}$ \\
\hline & $\begin{array}{l}\text { Compete }=\mathrm{GP}_{9} \\
\text { Note: in general terms, } \\
\text { the modalities of a video } \\
\text { game are easy, } \\
\text { intermediate and difficult }\end{array}$ & $\begin{array}{l}\mathrm{GP}_{9}=(c r+c g m+c t \\
+w g a) \\
\text { - Choice of rival = } \\
c r \\
\text { - Choice of game } \\
\text { mode }=c g m \\
\text { - Competition timer } \\
=c t \\
\text { - Winner for } \\
\text { greater } \\
\text { assertiveness = } \\
w g a\end{array}$ & 2.2 & $\begin{array}{l}c r \text { exists }=0.55 \\
c r \text { doesn't exist }=0.0 \\
c g m \text { exists }=0.55 \\
c g m \text { doesn't exist }=0.0 \\
c t \text { exists }=0.55 \\
c t \text { doesn't exist }=0.0 \\
w g a \text { exists }=0.55 \\
w g a \text { doesn't exist }=0.0\end{array}$ \\
\hline & $\begin{array}{l}\text { Co-ops }=\mathrm{GP}_{10} \\
\text { Note: in general terms, } \\
\text { the modalities of a video }\end{array}$ & $\begin{array}{l}\mathrm{GP}_{10}=(f c+c g m+g t \\
+w g a) \\
-\quad \text { Friend's choice }= \\
\quad f c\end{array}$ & 2.2 & $\begin{array}{l}f c \text { exists }=0.55 \\
f c \text { doesn't exist }=0.0 \\
c g m \text { exists }=0.55 \\
c g m \text { doesn't exist }=0.0\end{array}$ \\
\hline
\end{tabular}




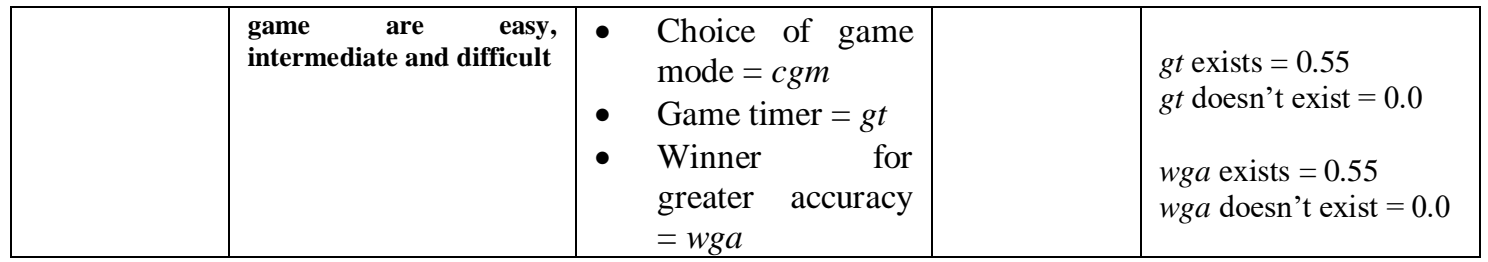

To get the GS value is necessary sum of its individual attributes, this is possible with the equation in equation 2.

$$
\begin{aligned}
G S=\sum_{i+1}^{n}\left[\left(\sum_{i+1}^{m} G S_{1}\right)+\left(\sum_{i+1}^{m} G S_{2}\right)+\left(\sum_{i+1}^{m} G S_{3}\right)+\left(\sum_{i+1}^{m} G S_{4}\right)+\left(\sum_{i+1}^{m} G S_{5}\right)+\left(\sum_{i+1}^{m} G S_{6}\right)\right. \\
+\left(\sum_{i+1}^{m} G S_{7}\right)+\left(\sum_{i+1}^{m} G S_{8}\right)+\left(\sum_{i+1}^{m} G S_{9}\right)+\left(\sum_{i+1}^{m} G S_{10}\right)+\left(\sum_{i+1}^{m} G S_{11}\right) \\
\left.+\left(\sum_{i+1}^{m} G S_{12}\right)\right]
\end{aligned}
$$

Equation 2. Equation of the Game System (GS) layer element

The desired result for the GS layer element is 24 , obtained from the sum of its 12 sub-attributes

\begin{tabular}{|c|c|c|c|c|}
\hline Attribute & Sub-Attribute & Metric & Weighting & Thresholds \\
\hline \multirow{3}{*}{ Narrative } & $\begin{array}{l}\text { Settings and } \\
\text { configuration } \\
=\mathrm{GS}_{1}\end{array}$ & $\begin{array}{l}\mathrm{GS}_{1}=(c c+s c) \\
\text { - } \quad \text { Control } \\
\text { components }=c c \\
\text { - } \quad \text { Storage of changes }= \\
s c\end{array}$ & 2.0 & $\begin{array}{l}c c \text { exists }=1.0 \\
c c \text { doesn't exist }=0.0 \\
s c \text { exists }=1.0 \\
s c \text { doesn't exist }=0.0 \\
\text { Note: is the software } \\
\text { component responsible for the } \\
\text { control of other components } \\
\text { for the control of accessibility, } \\
\text { ergonomics, keyboards and } \\
\text { sounds, among others }\end{array}$ \\
\hline & $\begin{array}{l}\text { Content }=\mathrm{GS}_{2} \\
\text { Note: the content is } \\
\text { the software } \\
\text { component } \\
\text { responsible for } \\
\text { loading the objects } \\
\text { or characters and } \\
\text { their rules of } \\
\text { movement and } \\
\text { behavior }\end{array}$ & $\begin{array}{l}\mathrm{GS}_{2}=(l o+r a+m o+ \\
d o) \\
\text { - } \quad \text { Loading objects }=l o \\
\text { - } \quad \begin{array}{l}\text { Response of actions } \\
=r a\end{array} \\
\text { - Movement of } \\
\text { objects = mo } \\
\text { Disappearance of } \\
\text { objects =do }\end{array}$ & 2.0 & $\begin{array}{l}\text { lo exists }=0.5 \\
l o \text { doesn't exist }=0.0 \\
r a \text { exists }=0.5 \\
r a \text { doesn't exist }=0.0 \\
m o \text { exists }=0.5 \\
m o \text { doesn't exist }=0.0 \\
d o \text { exists }=0.5 \\
d o \text { doesn't exist }=0.0 \\
\begin{array}{l}\text { Note: software component } \\
\text { based on the graphic design } \\
\text { pieces of a video game }\end{array}\end{array}$ \\
\hline & $\begin{array}{l}\text { Game world = } \\
\mathrm{GS}_{3} \\
\begin{array}{l}\text { Note: the game } \\
\text { world is the } \\
\text { software } \\
\text { component in }\end{array}\end{array}$ & $\begin{array}{l}\mathrm{GS}_{3}=(s l+s e+m r+p a) \\
\text { - } \quad \text { Stage load }=s l \\
\text { - } \quad \text { Stage events }=s e \\
\text { - } \quad \text { Movement rules }= \\
\quad m r \\
\text { - } \quad \text { Prohibited actions }=\end{array}$ & 2.0 & $\begin{array}{l}s l \text { exists }=0.5 \\
s l \text { doesn't exist }=0.0 \\
s e \text { exists }=0.5 \\
s e \text { doesn't exist }=0.0 \\
m r \text { exists }=0.5 \\
m r \text { doesn't exist }=0.0\end{array}$ \\
\hline
\end{tabular}
where each one has a maximum value of 2.0, using the metrics to evaluate in table 2 .

Table 2. Metrics of the Game System (GS) layer element of the Usability attribute 


\begin{tabular}{|c|c|c|c|c|}
\hline & $\begin{array}{l}\text { charge of loading } \\
\text { the visual content } \\
\text { and the rules of } \\
\text { movement of the } \\
\text { scenario }\end{array}$ & $p a$ & & $\begin{array}{l}p a \text { exists }=0.5 \\
p a \text { doesn't exist }=0.0 \\
\text { Note: software component } \\
\text { based on the graphic design } \\
\text { pieces of a video game }\end{array}$ \\
\hline \multirow{5}{*}{ Mechanic } & $\begin{array}{l}\text { Mechanics } \\
\text { coverage } \\
\mathrm{GS}_{4}\end{array}=$ & $\begin{array}{l}\mathrm{GS}_{4}=(c e o+r c c) \\
\text { - } \quad \text { Challenge for } \\
\text { established objective } \\
=\text { ceo } \\
\text { - Reward for } \\
\text { challenge completed } \\
=r c c\end{array}$ & 2.0 & $\begin{array}{l}c e o \text { exists }=1.0 \\
\text { ceo doesn't exist }=0.0 \\
r c c \text { equal to } \text { ceo }=1.0 \\
r c c \text { different to } c e o=0.0 \\
\text { Note: metric based on }[4]\end{array}$ \\
\hline & $\begin{array}{l}\text { Objective } \\
\text { coverage }= \\
\mathrm{GS}_{5}\end{array}$ & $\begin{array}{l}\mathrm{GS}_{5}=(\text { poi }) \\
\text { - All the proposed } \\
\text { objectives are } \\
\text { implemented = poi }\end{array}$ & 2.0 & $\begin{array}{l}\text { poi exists }=2.0 \\
\text { poi doesn't exist }=0.0 \\
\text { Note: metric based on }[4]\end{array}$ \\
\hline & Goals $=\mathrm{GS}_{6}$ & $\begin{array}{l}\mathrm{GS}_{6}=(e t+e e) \\
\text { - } \quad \text { Estimated } \\
\text { investment time }=e t \\
\text { - } \quad \text { Estimated } \\
\text { investment effort = } \\
e e\end{array}$ & 2.0 & 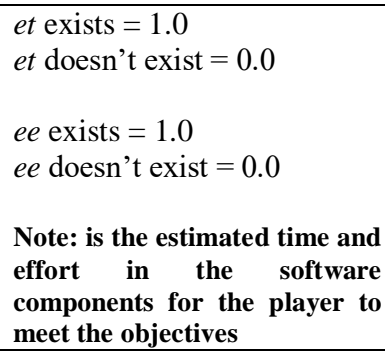 \\
\hline & $\begin{array}{l}\text { Rules } \\
\text { compliance = } \\
\mathrm{GS}_{7}\end{array}$ & $\begin{array}{l}\mathrm{GS}_{7}=(n s+c n s) \\
\text { - } \quad \begin{array}{l}\text { Normative, rules or } \\
\text { standard }=n s\end{array} \\
\text { Compliance } \\
\text { normative, rules of } \\
\text { standard }=\text { cns }\end{array}$ & 2.0 & $\begin{array}{l}n s \text { exists }=1.0 \\
n s \text { doesn't exist }=0.0 \\
\text { cns exists }=1.0 \\
\text { cns doesn't exist }=0.0 \\
\text { Note: is the regulation, norm } \\
\text { or standard of a particular } \\
\text { topic with educational content } \\
\text { for the player whose goal is to } \\
\text { be learned }\end{array}$ \\
\hline & Choices $=\mathrm{GS}_{8}$ & $\begin{array}{l}\mathrm{GS}_{8}=(p p+c c+c r p+ \\
c g m) \\
\text { - } \quad \text { Choice of player } \\
\text { profile }=p p \\
\text { - Choice of character } \\
=c c \\
\text { - Choice of the role of } \\
\text { the player }=c r p \\
\text { - Choice of game } \\
\text { mode }=c g m\end{array}$ & 2.0 & $\begin{array}{l}p p \text { exists }=0.5 \\
p p \text { doesn't exist }=0.0 \\
c c \text { exists }=0.5 \\
c c \text { doesn't exist }=0.0 \\
c r p \text { exists }=0.5 \\
c r p \text { doesn't exist }=0.0 \\
c g m \text { exists }=0.5 \\
c g m \text { doesn't exist }=0.0 \\
\begin{array}{l}\text { Note: is the component that } \\
\text { allows the player to select a } \\
\text { profile, character and game } \\
\text { mode before starting to play }\end{array}\end{array}$ \\
\hline Interface & $\begin{array}{l}\text { Sound } \\
\text { interaction } \\
\mathrm{GS}_{9}\end{array}$ & $\begin{array}{l}\mathrm{GS}_{9}=(s a+s e) \\
\text { - } \quad \text { Sound per actions = } \\
\text { - } \quad \text { Sounds per event }=\end{array}$ & 2.0 & $\begin{array}{l}s a \text { exists }=1.0 \\
s a \text { doesn't exist }=0.0 \\
s e \text { exists }=1.0 \\
s e \text { doesn't exist }=0.0\end{array}$ \\
\hline
\end{tabular}




\begin{tabular}{|c|c|c|c|}
\hline & se & & $\begin{array}{l}\text { Note: to motivate the player it } \\
\text { is recommended that there are } \\
\text { sounds per action and per } \\
\text { event }\end{array}$ \\
\hline Music $=\mathrm{GS}_{10}$ & $\begin{array}{l}\mathrm{GS}_{10}=(s m+b m+m l+ \\
\text { em }) \\
\text { - } \quad \text { Start music }=s m \\
\text { - } \quad \text { Background music }= \\
\quad b m \\
\text { - } \quad \text { Music by level }=m l \\
\text { - } \quad \text { End music }=e m\end{array}$ & 2.0 & 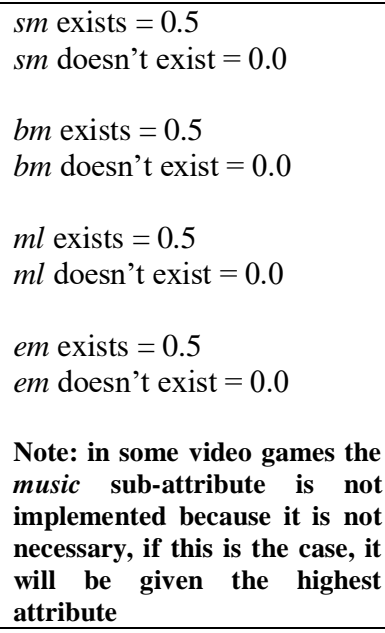 \\
\hline $\begin{array}{l}\text { Training } \\
\mathrm{GS}_{11}\end{array}$ & $\begin{array}{l}\mathrm{GS}_{11}=(p l+m t h+\text { aim }) \\
\text { Practice level }=p l \\
\text { - } \quad \text { Mode to try again } \\
\text { with help }=m t h \\
\text { - Artificial } \\
\text { intelligence mode = } \\
\text { aim }\end{array}$ & 2.0 & $\begin{array}{l}p l \text { exists }=0.75 \\
p l \text { doesn't exist }=0.0 \\
\text { mth exists }=0.75 \\
m t h \text { doesn't exist }=0.0 \\
\text { aim exists }=0.5 \\
\text { aim doesn't exist }=0.0 \\
\text { Note: the artificial intelligence } \\
\text { is a very complex software } \\
\text { component to develop and not } \\
\text { all video games have, for this } \\
\text { reason it receives a lower value } \\
{[11]}\end{array}$ \\
\hline $\begin{array}{l}\text { Ways of } \\
\text { interacting = } \\
\mathrm{GS}_{12}\end{array}$ & $\begin{array}{l}\mathrm{GS}_{12}=(i w i+i w h+i t e) \\
\text { - } \quad \text { Interact with } \\
\text { instructions }=i w i \\
\text { - } \quad \begin{array}{l}\text { Interact without help } \\
=i w h\end{array} \\
\text { - } \quad \text { Interact to trial and } \\
\text { error = ite }\end{array}$ & 2.0 & $\begin{array}{l}i w i \text { exists }=0.7 \\
i w i \text { doesn't exist }=0.0 \\
i w h \text { exists }=0.65 \\
i w h \text { doesn't exist }=0.0 \\
\text { ite exists }=0.65 \\
\text { ite doesn't exist }=0.0 \\
\text { Note: is the way in which the } \\
\text { player receives or does not } \\
\text { receive help from the game }\end{array}$ \\
\hline
\end{tabular}

To measure the understandability attribute, the results obtained in the Game Interface (GI), Game Engine (GE) and the Game Mechanic (GM) will be considered. The desired result for the understandability attribute is 54, obtained from the sum between the GI, GE and GM layer elements. To obtain the value of the understandability attribute is used Understandability $=(\mathrm{GI}+$ $\mathrm{GE}+\mathrm{GM})$.

To get the GI value is necessary sum of its individual attributes, this is possible with the equation in equation 3. 


$$
G I=\sum_{i+1}^{n}\left[\left(\sum_{i+1}^{m} G I_{1}\right)+\left(\sum_{i+1}^{m} G I_{2}\right)+\left(\sum_{i+1}^{m} G I_{3}\right)+\left(\sum_{i+1}^{m} G I_{4}\right)+\left(\sum_{i+1}^{m} G I_{5}\right)+\left(\sum_{i+1}^{m} G I_{6}\right)\right]
$$

Equation 3. Equation of the Game Interface (GI) layer element

The desired result for the GI layer element is 18, obtained from the sum of its 6 sub-attributes where each one has a maximum value of 3.0 , using the metrics to evaluate in table 3 .

Table 3. Metrics of the Game Interface (GI) layer element of the Understandability attribute

\begin{tabular}{|c|c|c|c|c|}
\hline Attribute & $\begin{array}{c}\text { Sub- } \\
\text { Attribute }\end{array}$ & Metric & Weighting & Thresholds \\
\hline \multirow{3}{*}{ Clarity } & $\begin{array}{l}\text { Objectives = } \\
\mathrm{GI}_{1}\end{array}$ & $\begin{array}{l}\mathrm{GI}_{1}=(b o+c o) \\
\text { - } \quad \text { Brief objectives = } \\
\text { bo } \\
\text { - } \quad \begin{array}{l}\text { Clear objectives = } \\
\text { co }\end{array}\end{array}$ & 3.0 & $\begin{array}{l}b o \text { are }=1.5 \\
b o \text { are not }=0.0 \\
c o \text { are }=1.5 \\
c o \text { are not }=0.0\end{array}$ \\
\hline & Rules $=\mathrm{GI}_{2}$ & $\begin{array}{l}\mathrm{GI}_{2}=(b r+c r) \\
\text { - } \quad \text { Brief rules }=b r \\
\text { - }\end{array}$ & 3.0 & $\begin{array}{l}b r \text { are }=1.5 \\
b r \text { are not }=0.0 \\
c r \text { are }=1.5 \\
c r \text { are not }=0.0\end{array}$ \\
\hline & $\begin{array}{l}\text { Ergonomics } \\
\text { of the } \\
\text { environment } \\
=\mathrm{GI}_{3}\end{array}$ & $\begin{array}{l}\mathrm{GI}_{3}=(m n o+c p h) \\
\text { - } \quad \begin{array}{l}\text { Maximum number } \\
\text { of objects that the } \\
\text { user can perceive } \\
=\text { mno } \\
\text { Colors } \\
\text { animations } \\
\text { phosphorescent or } \\
\text { with luminescence } \\
=c p h\end{array} \\
\end{array}$ & 3.0 & $\begin{array}{l}m n o \leq 4=1.5 \\
4<m n o \leq 6=1.125 \\
6<m n o \leq 8=0.75 \\
8<m n o \leq 10=0.375 \\
m n o>10=0.0 \\
c p h \text { has }=0.0 \\
c p h \text { has not }=1.5 \\
\text { Note: metric based on }[12]\end{array}$ \\
\hline \multirow[t]{2}{*}{ Readability } & $\begin{array}{l}\text { Orthography } \\
=\mathrm{GI}_{4}\end{array}$ & $\begin{array}{l}\mathrm{GI}_{4}=(m p+p s+a c l) \\
\text { - } \text { Misspellings }=m p \\
\text { - } \quad \text { Punctuations }=p s \\
\text { - Alternation of } \\
\text { capital letters = } \\
\text { acl }\end{array}$ & 3.0 & $\begin{array}{l}m p \text { has }=0.0 \\
m p \text { has not }=1.0 \\
p s \text { has }=1.0 \\
p s \text { has not }=0.0 \\
a c l \text { has }=1.0 \\
a c l \text { has not }=0.0 \\
\begin{array}{l}\text { Note: they are basic but } \\
\text { obligatory aspects for } \\
\text { understanding the text in the } \\
\text { serious video game }\end{array}\end{array}$ \\
\hline & $\begin{array}{l}\text { Concurrency } \\
\text { of words = } \\
\mathrm{GI}_{5}\end{array}$ & $\begin{array}{ll}\mathrm{GI}_{5}= & (r w+w s+s p) \\
\text { - } & \text { Repeated words }= \\
& r w \\
- & \text { Words stuck }=w s \\
- & \text { Separated } \\
& \text { paragraphs }=s p\end{array}$ & 3.0 & $\begin{array}{l}r w \text { has }=0.0 \\
r w \text { has not }=1.0 \\
w s \text { has }=0.0 \\
w s \text { has not }=1.0 \\
s p \text { has }=1.0 \\
s p \text { has not }=0.0 \\
\begin{array}{l}\text { Note: they are basic but } \\
\text { obligatory aspects for }\end{array}\end{array}$ \\
\hline
\end{tabular}




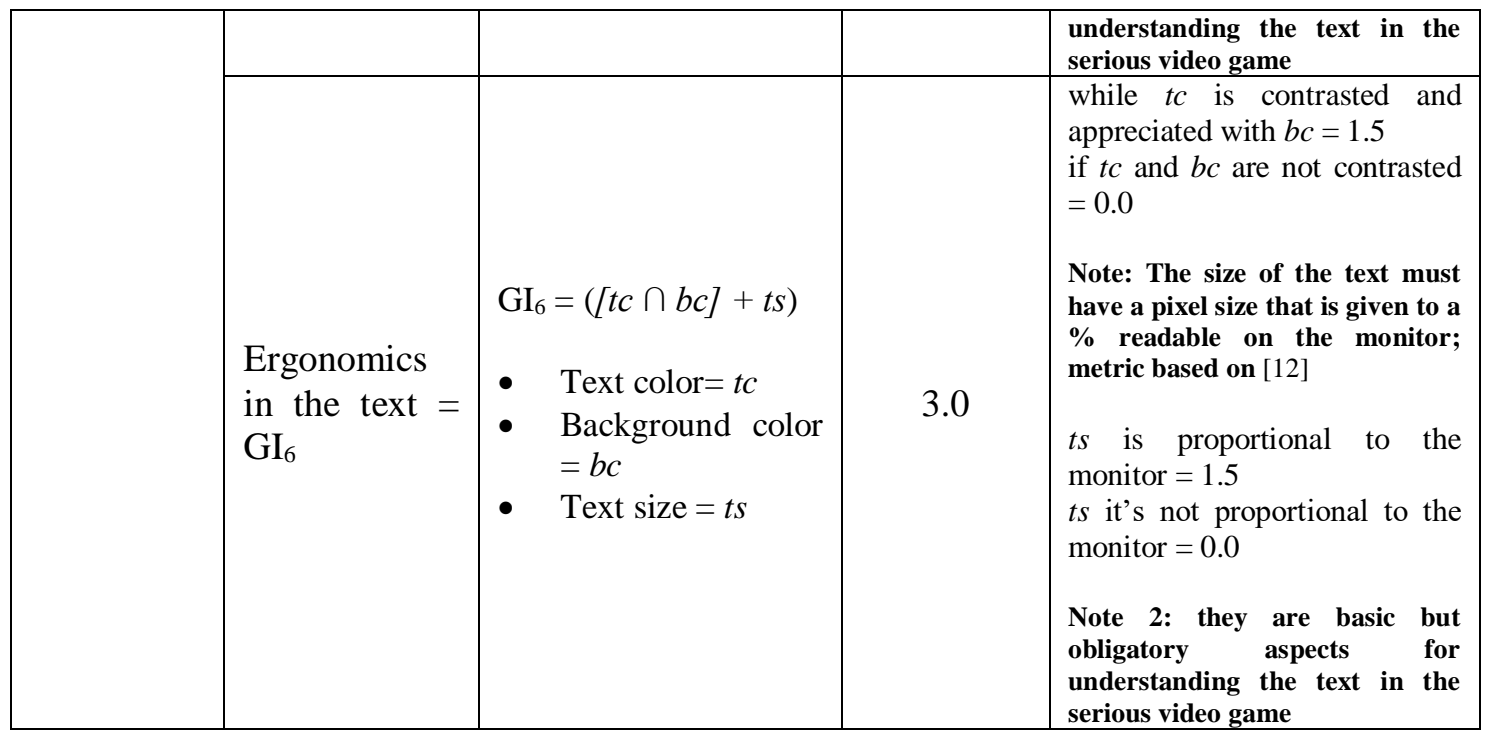

To get the GE value is necessary sum of its individual attributes, this is possible with the equation in equation 4.

$$
\begin{aligned}
G E=\sum_{i+1}^{n} & {\left[\left(\sum_{i+1}^{m} G E_{1}\right)+\left(\sum_{i+1}^{m} G E_{2}\right)+\left(\sum_{i+1}^{m} G E_{3}\right)+\left(\sum_{i+1}^{m} G E_{4}\right)+\left(\sum_{i+1}^{m} G E_{5}\right)+\left(\sum_{i+1}^{m} G E_{6}\right)\right.} \\
& \left.+\left(\sum_{i+1}^{m} G E_{7}\right)+\left(\sum_{i+1}^{m} G E_{8}\right)\right]
\end{aligned}
$$

Equation 4. Equation of the Game Engine (GE) layer element

The desired result for the GE layer element is 18, obtained from the sum of its 8 sub-attributes where each one has a maximum value of 2.25 , using the metrics to evaluate in table 4 .

\begin{tabular}{|c|c|c|c|c|}
\hline Attribute & Sub-Attribute & Metric & Weighting & Thresholds \\
\hline \multirow{3}{*}{ Rendering } & $\begin{array}{l}\text { Delimitations } \\
=\mathrm{GE}_{1}\end{array}$ & 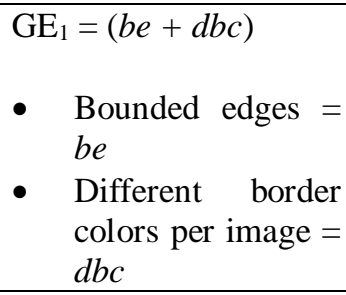 & 2.25 & $\begin{array}{l}b e \text { has }=1.125 \\
b e \text { has not }=0.0 \\
d b c \text { has }=1.125 \\
d b c \text { has not }=0.0\end{array}$ \\
\hline & $\begin{array}{l}\text { Over-position } \\
=\mathrm{GE}_{2}\end{array}$ & $\begin{array}{l}\mathrm{GE}_{2}=(m s) \\
\text { - } \begin{array}{l}\text { Margin } \\
\text { shadows }=m s\end{array} \text { or }\end{array}$ & 2.25 & $\begin{array}{l}b e \text { has }=2.25 \\
b e \text { has not }=0.0 \\
\text { Note: metric based on [12] }\end{array}$ \\
\hline & $\begin{array}{l}\text { Stream of } \\
\text { sequence } \\
\mathrm{GE}_{3}\end{array}$ & 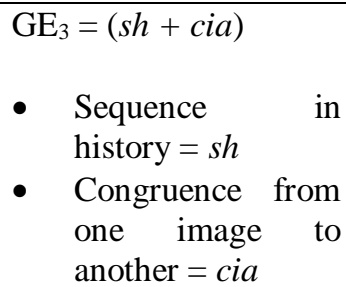 & 2.25 & $\begin{array}{l}s h \text { are }=1.125 \\
s h \text { are not }=0.0 \\
\text { cia are }=1.125 \\
\text { cia } \text { are not }=0.0\end{array}$ \\
\hline
\end{tabular}

Table 4. Metrics of the Game Engine (GI) layer element of the Understandability attribute 


\begin{tabular}{|c|c|c|c|c|}
\hline \multirow{2}{*}{ Visual aid } & $\begin{array}{l}\text { Guidance } \\
\text { indications = } \\
\mathrm{GE}_{4}\end{array}$ & $\begin{array}{l}\mathrm{GE}_{4}=(d s+i a) \\
\text { - } \quad \text { Directional signals } \\
=d s \\
\text { - } \quad \text { Help comments = } \\
h c\end{array}$ & 2.25 & $\begin{array}{l}d s \text { has }=1.125 \\
d s \text { has not }=0.0 \\
h c \text { has }=1.125 \\
h c \text { has not }=0.0 \\
\text { Note: metric based on }[13]\end{array}$ \\
\hline & $\begin{array}{l}\text { Over-position } \\
=\mathrm{GE}_{5}\end{array}$ & $\begin{array}{l}\mathrm{GE}_{5}=(f l+s i) \\
\text { - } \quad \text { Flashing lights }=f l \\
\text { - } \quad \text { Superimposed } \\
\quad \text { image }=s i\end{array}$ & 2.25 & $\begin{array}{l}f l \text { has }=1.125 \\
f l \text { has not }=0.0 \\
\text { si has }=1.125 \\
\text { si has not }=0.0 \\
\text { Note: metric based on }[13]\end{array}$ \\
\hline \multirow{3}{*}{$\begin{array}{l}\text { Context } \\
\text { of use }\end{array}$} & $\begin{array}{l}\text { Illumination = } \\
\mathrm{GE}_{6}\end{array}$ & $\begin{array}{l}\mathrm{GE}_{6}=([b s \cap c t]) \\
\text { - } \quad \text { Brightness }=b s \\
\text { - } \quad \text { Contrast }=c t\end{array}$ & 2.25 & 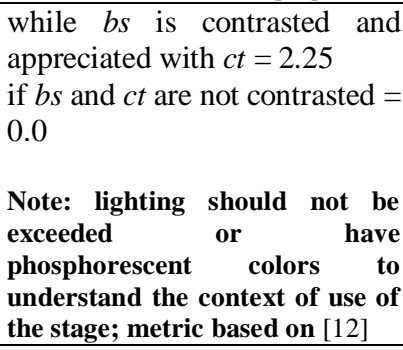 \\
\hline & $\begin{array}{l}\text { Audio notes = } \\
\mathrm{GE}_{7}\end{array}$ & $\begin{array}{ll}\mathrm{GE}_{7}=(c v+t b) \\
-\quad \text { Clear voice }=c v \\
-\quad \text { Time breaks }=t b\end{array}$ & 2.25 & $\begin{array}{l}c v \text { has }=1.125 \\
c v \text { has not }=0.0 \\
t b \text { has }=1.125 \\
t b \text { has not }=0.0\end{array}$ \\
\hline & $\begin{array}{l}\text { Physical } \\
\text { environment = } \\
\mathrm{GE}_{8}\end{array}$ & $\begin{array}{l}\mathrm{GE}_{8}=(r a+i a+t a+ \\
[c e \cap p e]) \\
\text { - } \quad \text { Reading actions }= \\
\text { - } \quad \text { Interaction actions } \\
\quad=i a \\
\text { - } \quad \text { Trigger actions }= \\
\text { - } a \\
\text { - } \quad \text { Controllable } \\
\text { elements }=c e \\
\text { - Predictable } \\
\text { elements }=p e\end{array}$ & 2.25 & $\begin{array}{l}r a \text { has }=0.45 \\
r a \text { has not }=0.0 \\
i a \text { has }=0.45 \\
i a \text { has not }=0.0 \\
t a \text { has }=0.45 \\
t a \text { has not }=0.0 \\
\text { while } c e \text { interacts with } p e=0.9 \\
\text { if } c e \text { and pe do not interact }= \\
0.0 \\
\text { Note: } \text { metric based on }[12]\end{array}$ \\
\hline
\end{tabular}

To get the GM value is necessary sum of its individual attributes, this is possible with the equation in equation 5.

$$
G M=\sum_{i+1}^{n}\left[\left(\sum_{i+1}^{m} G M_{1}\right)+\left(\sum_{i+1}^{m} G M_{2}\right)+\left(\sum_{i+1}^{m} G M_{3}\right)+\left(\sum_{i+1}^{m} G M_{4}\right)+\left(\sum_{i+1}^{m} G M_{5}\right)+\left(\sum_{i+1}^{m} G M_{6}\right)\right]
$$

Equation 5. Equation of the Game Mechanic (GM) layer element

The desired result for the GM layer element is 18 , obtained from the sum of its 6 sub-attributes where each one has a maximum value of 3.0 , using the metrics to evaluate in table 5 . 
Table 5. Metrics of the Game Mechanic (GM) layer element of the Understandability attribute

\begin{tabular}{|c|c|c|c|c|}
\hline Attribute & Sub-Attribute & Metric & Weighting & Thresholds \\
\hline \multirow{3}{*}{ Interactivity } & $\begin{array}{l}\text { Game } \\
\text { commands = } \\
\mathrm{GM}_{1}\end{array}$ & $\begin{array}{l}\mathrm{GM}_{1}=(s c) \\
\text { - } \begin{array}{l}\text { Sense } \\
\text { control = } s c\end{array}\end{array}$ & 3.0 & $\begin{array}{l}s c \text { is reliable }=3.0 \\
s c \text { it's not reliable }=0.0 \\
\text { Note: the feeling of the } \\
\text { commands or the control for } \\
\text { the adaptation of the } \\
\text { player's interactivity; metric } \\
\text { based on }[13,14]\end{array}$ \\
\hline & $\begin{array}{l}\text { Help options = } \\
\mathrm{GM}_{2}\end{array}$ & $\begin{array}{l}\mathrm{GM}_{2}=(h i+d i a) \\
\text { - } \\
\text { Delp icon }=h i \\
\text { Description or } \\
\text { activity } \\
\text { information = } \\
\text { dia }\end{array}$ & 3.0 & $\begin{array}{l}\text { hi has }=1.5 \\
\text { hi has not }=0.0 \\
\text { dia has }=1.5 \\
\text { dia has not }=0.0 \\
\text { Note: are buttons that give } \\
\text { us help or information about } \\
\text { the level or activity to be } \\
\text { performed }\end{array}$ \\
\hline & $\begin{array}{l}\text { Game } \\
\text { sequence } \\
\mathrm{GM}_{3}\end{array}$ & $\begin{array}{l}\mathrm{GM}_{3}=(\mathrm{cfa}) \\
\text { - Sequence for } \\
\text { the final } \\
\text { achievement }= \\
c f a\end{array}$ & 3.0 & $\begin{array}{l}c f a \text { has }=3.0 \\
c f a \text { has not }=0.0 \\
\text { Note: it's the preparation in } \\
\text { the understanding of the } \\
\text { game, activity by activity, } \\
\text { level by level, to complete } \\
\text { the game }\end{array}$ \\
\hline \multirow{3}{*}{$\begin{array}{l}\text { Self- } \\
\text { Descriptiveness }\end{array}$} & $\begin{array}{l}\text { Instructions = } \\
\mathrm{GM}_{4}\end{array}$ & $\begin{array}{l}\mathrm{GM}_{4}=(\mathrm{sag}+\text { iss }) \\
\text { - } \quad \text { Short and brief } \\
\text { guide = sag } \\
\text { Indications } \\
\text { step by step = } \\
\text { iss }\end{array}$ & 3.0 & $\begin{array}{l}\text { sag has }=1.5 \\
\text { sag has not }=0.0 \\
\text { iss has }=1.5 \\
\text { iss has not }=0.0\end{array}$ \\
\hline & $\begin{array}{l}\text { Related icons = } \\
\mathrm{GM}_{5}\end{array}$ & $\begin{array}{l}\mathrm{GM}_{5}=(\mathrm{icm}) \\
\text { Icon alluding } \\
\text { to the action or } \\
\text { menu }=i \mathrm{~cm}\end{array}$ & 3.0 & $\begin{array}{l}i \mathrm{~cm} \text { has }=3.0 \\
i \mathrm{~cm} \text { has not }=0.0\end{array}$ \\
\hline & $\begin{array}{l}\text { Light colors = } \\
\mathrm{GM}_{6}\end{array}$ & $\begin{array}{l}\mathrm{GM}_{6}=(s r s) \\
\text { - } \quad \text { Soft } \\
\text { recognizable } \\
\text { shades = srs }\end{array}$ & 3.0 & $\begin{array}{l}\text { srs has }=3.0 \\
\text { srs has not }=0.0 \\
\text { Note: are certain shades that } \\
\text { have the lights of the colors, } \\
\text { like the red that represents } \\
\text { error or the green that } \\
\text { resembles something correct }\end{array}$ \\
\hline
\end{tabular}

\subsection{Desired values assigned}

The representation of each desired value that has been assigned to the attributes in this proposed quality model for playability in serious video games can be seen more simply in table 6 , which represent the estimated value for each metric proposed in figure 6. 
Table 6. Desired values assigned to the attributes of the Quality Model for the Playability

\begin{tabular}{|c|c|c|c|c|}
\hline $\begin{array}{l}\text { Context } \\
\text { Quality }\end{array}$ & $\begin{array}{c}\text { Quality } \\
\text { Attribute }\end{array}$ & Component & Sub-Attribute Metric & $\begin{array}{c}\text { Desired } \\
\text { Value }\end{array}$ \\
\hline \multirow{42}{*}{ 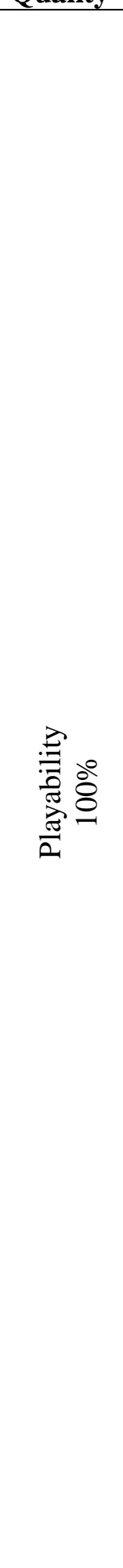 } & \multirow{22}{*}{ 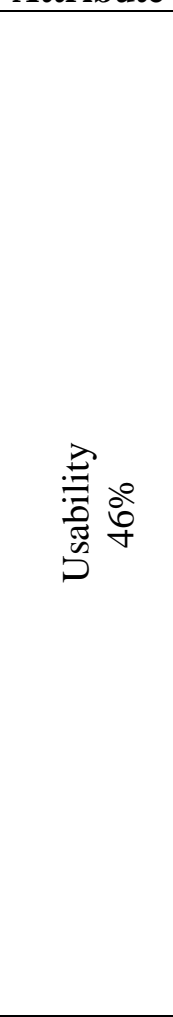 } & \multirow{10}{*}{ 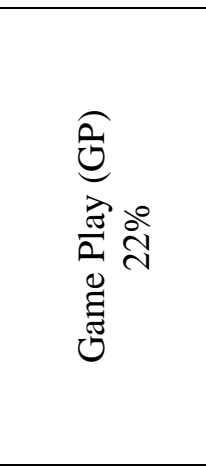 } & Learning curve $=\mathrm{GP}_{1}$ & $2.2 \%$ \\
\hline & & & Feedback $=\mathrm{GP}_{2}$ & $2.2 \%$ \\
\hline & & & Challenges $=\mathrm{GP}_{3}$ & $2.2 \%$ \\
\hline & & & Appropriateness of reward $=\mathrm{GP}_{4}$ & $2.2 \%$ \\
\hline & & & Decision making $=\mathrm{GP}_{5}$ & $2.2 \%$ \\
\hline & & & Place $=\mathrm{GP}_{6}$ & $2.2 \%$ \\
\hline & & & Role $=\mathrm{GP}_{7}$ & $2.2 \%$ \\
\hline & & & Response of controls $=\mathrm{GP}_{8}$ & $2.2 \%$ \\
\hline & & & Compete $=\mathrm{GP}_{9}$ & $2.2 \%$ \\
\hline & & & Co-ops $=\mathrm{GP}_{10}$ & $2.2 \%$ \\
\hline & & \multirow{12}{*}{ 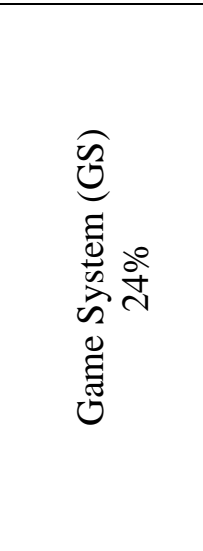 } & Settings and configuration $=\mathrm{GS}_{1}$ & $2.0 \%$ \\
\hline & & & Content $=\mathrm{GS}_{2}$ & $2.0 \%$ \\
\hline & & & Game world $=\mathrm{GS}_{3}$ & $2.0 \%$ \\
\hline & & & Mechanics coverage $=\mathrm{GS}_{4}$ & $2.0 \%$ \\
\hline & & & Objective coverage $=\mathrm{GS}_{5}$ & $2.0 \%$ \\
\hline & & & Goals $=\mathrm{GS}_{6}$ & $2.0 \%$ \\
\hline & & & Rules compliance $=\mathrm{GS}_{7}$ & $2.0 \%$ \\
\hline & & & Choices $=\mathrm{GS}_{8}$ & $2.0 \%$ \\
\hline & & & Sound interaction $=\mathrm{GS}_{9}$ & $2.0 \%$ \\
\hline & & & Music $=\mathrm{GS}_{10}$ & $2.0 \%$ \\
\hline & & & Training $=\mathrm{GS}_{11}$ & $2.0 \%$ \\
\hline & & & Ways of interacting $=\mathrm{GS}_{12}$ & $2.0 \%$ \\
\hline & \multirow{20}{*}{ 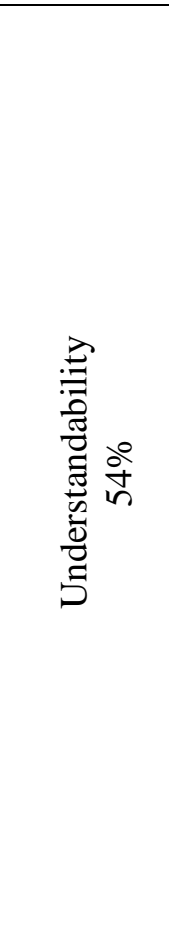 } & \multirow{6}{*}{ 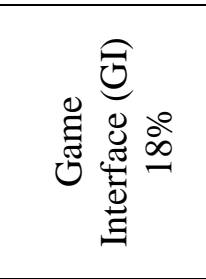 } & Objectives $=\mathrm{GI}_{1}$ & $3.0 \%$ \\
\hline & & & Rules $=\mathrm{GI}_{2}$ & $3.0 \%$ \\
\hline & & & Ergonomics of the environment $=\mathrm{GI}_{3}$ & $3.0 \%$ \\
\hline & & & Orthography $=\mathrm{GI}_{4}$ & $3.0 \%$ \\
\hline & & & Concurrency of words $=\mathrm{GI}_{5}$ & $3.0 \%$ \\
\hline & & & Ergonomics in the text $=\mathrm{GI}_{6}$ & $3.0 \%$ \\
\hline & & \multirow{8}{*}{ 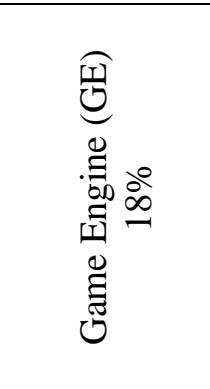 } & Delimitations $=\mathrm{GE}_{1}$ & $2.25 \%$ \\
\hline & & & Over-position $=\mathrm{GE}_{2}$ & $2.25 \%$ \\
\hline & & & Stream of sequence $=\mathrm{GE}_{3}$ & $2.25 \%$ \\
\hline & & & Guidance indications $=\mathrm{GE}_{4}$ & $2.25 \%$ \\
\hline & & & Over-position $=\mathrm{GE}_{5}$ & $2.25 \%$ \\
\hline & & & Illumination $=\mathrm{GE}_{6}$ & $2.25 \%$ \\
\hline & & & Audio notes $=\mathrm{GE}_{7}$ & $2.25 \%$ \\
\hline & & & Physical environment $=\mathrm{GE}_{8}$ & $2.25 \%$ \\
\hline & & \multirow{6}{*}{ 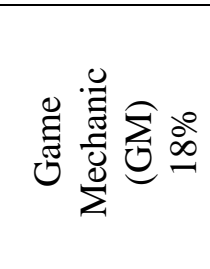 } & Game commands $=\mathrm{GM}_{1}$ & $3.0 \%$ \\
\hline & & & Help options $=\mathrm{GM}_{2}$ & $3.0 \%$ \\
\hline & & & Game sequence $=\mathrm{GM}_{3}$ & $3.0 \%$ \\
\hline & & & Instructions $=\mathrm{GM}_{4}$ & $3.0 \%$ \\
\hline & & & Related icons $=\mathrm{GM}_{5}$ & $3.0 \%$ \\
\hline & & & Light colors $=\mathrm{GM}_{6}$ & $3.0 \%$ \\
\hline
\end{tabular}

Where there is an equivalence between the 5 layers that subdivide the two attributes that make up the Playability in the context of Serious Video Games for this proposed model. 


\section{RESULTS AND DISCUSSION}

The metrics proposed in tables 1 to 5 will be considered concerning the desired values in the quality model presented in table 6 , to determine how well each version of the serious video game meets in the quality measurement.

The serious video game selected for the test case was a game that is being developed by 'Instituto Tecnológico Superior de Escárcega (ITSE)' in Escarcega, Mexico. Whose purpose is to learn geometry by solving exercises of different difficulty, through the intensive practice of logical reasoning. And drastically improve the skills for logical reasoning, creating mathematical demonstrations, and solving geometric puzzles.

The experimental results obtained in table 7 indicate that not all the attributes selected in the quality model can be adjusted to the needs of the serious video game. For this reason, it is recommended to consider only the metrics that are adapted to serious video games during the analysis to development phases.

Table 7. Experimental results of the test case for the Quality Model in Serious Video Games

\begin{tabular}{|l|c|c|c|}
\hline \multicolumn{1}{|c|}{ Context } & Desired Value & Summation & Reached \\
\hline Usability & 46.0 & 37.120 & $80.695 \%$ \\
\hline Understandability & 54.0 & 50.925 & $94.305 \%$ \\
\hline Playability & 100.0 & 88.045 & $88.045 \%$ \\
\hline
\end{tabular}

\section{Conclusions}

The structure of the quality model is categorized in such a way that criteria are taken when analysing and developing the software components in a serious video game, to increase the success in the final goal that is to achieve learning about a subject to the player.

Although the proposed model is aimed at serious video games, it may be applicable to classic video games or entertainment purposes.

As future work, the proposed model is flexible to the measurement of different serious video games and allows to obtain an approximate range of the quality of the playability and is open to extensions so that it can be thoroughly detailed or extended to other components for the development of games, such as challenges and rewards in the mechanics of understandability. The addition of metrics in the saved and stored options of the usability game scenarios, and it can even be extended to other quality attributes applicable to Serious Video Games.

\section{ACKNOWLEDGEMENTS}

Special thanks to Ph. D. Olivia Graciela Fragoso Diaz and the 'Centro Nacional de Investigación y Desarrollo Tecnológico (CENIDET)' in Cuernavaca, Mexico. For their collaboration in this research work. 


\section{REFERENCES}

[1] Calvo-Ferrer, J. R. (2018). Juegos, videojuegos y juegos serios: Análisis de los factores que favorecen la diversión del jugador, Mhjc no. 9, artículo 7, pp. 191-226. http://dx.doi.org/10.21134/mhcj.v0i9.232.

[2] González-Sánchez, J. L.; Padilla-Zea, N. \& Vela, F. L. G. (2009). From Usability to Playability: Introduction to Player-Centred Video Game Development Process, Human Centered. First International Conference, HCD, pp. 65-74. https://doi.org/10.1007/978-3-642-02806-9_9.

[3] Standards Coordinating Committee of the IEEE Computer Society. (1991). IEEE Standard Computer Dictionary, A Compilation of IEEE Standard Computer Glossaries, pp. 610-1990. https://doi.org/10.1109/IEEESTD.1991.106963.

[4] García-Mundo, L.; Genero, M. \& Piattini, M. (2015). Applying a Serious Game Quality Model, Springer. Serious Games, Interaction, and Simulation. 5th International Conference, SGAMES 2015, pp. 21-29. DOI 10.1007/978-3-319-29060-7.

[5] Desurvire, H. \& Wiberg, C. (2010). Chapter 8. User Experience Design for Inexperienced Gamers: GAP - Game Approachability, Evaluating User Experience in Games. Concepts and Methods. Springer. Regina Bernhaupt (Ed.), pp. 131-148. DOI 10.1007/978-1-84882-963-3_3.

[6] Chittaro, L. (2015). Designing Serious Games for Safety Education: "Learn to Brace" vs. Traditional Pictorials for Aircraft Passengers. IEEE Transactions on Visualization and Computer Graphics. Vol. 22, Issue 5, pp. 1527-1539. DOI: 10.1109/TVCG.2015.2443787.

[7] Calvillo-Gámez, E. H.; Cairns, P. \& Cox, A. L. (2010). Chapter 4. Assessing the Core Elements of the Gaming Experience, Evaluating User Experience in Games. Concepts and Methods. Springer. Regina Bernhaupt (Ed.), pp. 47-72. DOI 10.1007/978-1-84882-963-3_3.

[8] Figueredo, Ó. B. (2015). Informaster: un juego serio para desarrollar competencias en manejo de información, Opción, Año 31, No. Especial 4. Universidad de La Sabana de Chía, Colombia, pp. $127-$ 146. ISSN 1012-1587.

[9] Povedano, D. G. (2013). Desarrollo de videojuegos sobre la plataforma Android, Facultad de Informática de Barcelona, pp. 11-24. http://hdl.handle.net/2099.1/14016.

[10] Takatalo, J.; Häkkinen, J.; Kaistinen, J. \& Nyman, G. (2010). Chapter 3. Presence, Involvement, and Flow in Digital Games, Evaluating User Experience in Games. Concepts and Methods. Springer. Regina Bernhaupt (Ed.), pp. 23-46. DOI 10.1007/978-1-84882-963-3_3.

[11] Safadi, F.; Fonteneau, R. \& Ernst, D. (2015). Artificial Intelligence in Video Games: Towards a Unified Framework, International Journal of Computer Games Technology. Volume 2015, Article ID 271296, pp. 1-30. DOI: 0.1155/2015/271296.

[12] Verdú, F. M. M. (2007). La investigación en riesgos ergonómicos: Ergonomía Visual, Universidad de Alicante. Riesgos ergónomicos y psicosociales: los nuevos determinantes para la salud de los trabajadores, pp. 1-52.

[13] Cañas Delgado, J. J. (2011). Ergonomía en los sistemas de trabajo, Granada: Secretaría de Salud Laboral de la UGT-CEC.

[14] Wilson, S. N.; Elizondo, J.; Ralston, R.; Lee, Y.-H.; Lee, Y.-H.; Kornelson, K.; Savic, M.; Stewart, S.; Lennox, E. \& Thompson, W. (2016). Digital Game for Undergraduate Calculus Education: The Affordances of Game Design and its Effects on Immersion, Calculation, and Conceptual Understanding, International Journal of Gaming and Computer-Mediated Simulations. Vol. 8 Issue 1, pp. 13-27. DOI: 10.4018/IJGCMS.2016010102. 


\section{AUTHORS}

Iván Humberto Fuentes Chab (ivanfuentes@ itsescarcega.edu.mx) received M. Computer Science from 'Centro Nacional de Investigación y Desarrollo Tecnológico (CENIDET)', Cuernavaca (Mexico) in 2019 \& B.E Computer Systems for 'Instituto Tecnológico de Campeche', Campeche (Mexico) in 2017. He currently teaches at the 'Instituto Tecnológico Superior de Escárcega' in Escarcega, Mexico.

Damián Uriel Rosado Castellanos (damianrc@itsescarcega.edu.mx) received M. Computer Science from 'Centro Nacional de Investigación y Desarrollo Tecnológico (CENIDET)', Cuernavaca (Mexico) in 2018 \& B.E Computer Systems for 'Instituto Tecnológico de Campeche', Campeche (Mexico) in 2016. He currently teaches at the 'Instituto Tecnológico Superior de Escárcega' in Escarcega, Mexico.

Dr. Olivia Graciela Fragoso Diaz (olivia.fd@ cenidet.tecnm.mx) Ph.D. in Computer Science for University of Manchester Institute of Science and Technology (UMIST), Manchester (United Kingdom) in 2012 \& M. Computer Science from 'Centro Nacional de Investigación y Desarrollo Tecnológico (CENIDET)', Cuernavaca (Mexico). She currently teaches at the 'Centro Nacional de Investigación y Desarrollo Tecnológico (CENIDET)' in Cuernavaca, Mexico.

Ivette Stephany Pacheco Farfán (ipacheco@itsescarcega.edu.mx) received M. Computer Science, Campeche (México) in 2020 for 'Universidad Hispanoamericana Justo Sierra' \& B.E Computer Systems for 'Universidad Autónoma de Campeche', Campeche (México) in 2010. She currently teaches at the 'Instituto Tecnológico Superior de Escárcega' in Escarcega, Mexico.
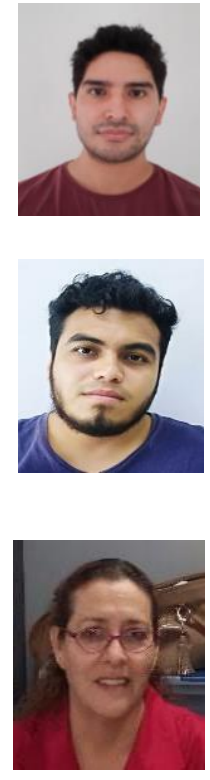

(C) 2020 By AIRCC Publishing Corporation. This article is published under the Creative Commons Attribution (CC BY) license. 